\title{
Author Correction: Engineering monocyte/ macrophage-specific glucocerebrosidase expression in human hematopoietic stem cells using genome editing
}

Samantha G. Scharenberg (1D), Edina Poletto (1D, Katherine L. Lucot (1D, Pasqualina Colella (1D, Adam Sheikali, Thomas J. Montine, Matthew H. Porteus (1) \& Natalia Gomez-Ospina (1)

Correction to: Nature Communications https://doi.org/10.1038/s41467-020-17148-x, published online 03 July 2020.

The original version of this Article contained errors in the abstract. In three instances within the abstract, the enzyme glucocerebrosidase was incorrectly referred to as its substrate glucocerebroside. The error has been corrected in the HTML and the PDF of the original version of the Article.

Published online: 20 August 2020

(c) (i) Open Access This article is licensed under a Creative Commons Attribution 4.0 International License, which permits use, sharing, adaptation, distribution and reproduction in any medium or format, as long as you give appropriate credit to the original author(s) and the source, provide a link to the Creative Commons license, and indicate if changes were made. The images or other third party material in this article are included in the article's Creative Commons license, unless indicated otherwise in a credit line to the material. If material is not included in the article's Creative Commons license and your intended use is not permitted by statutory regulation or exceeds the permitted use, you will need to obtain permission directly from the copyright holder. To view a copy of this license, visit http://creativecommons.org/licenses/by/4.0/.

(c) The Author(s) 2020 